\title{
Pelatihan Keterampilan MC Dan Dirigen Ibu-Ibu Pkk Desa Kincang Kecamatan Jiwan Kabupaten Madiun
}

\author{
Maria Magdalena Widiantari ${ }^{1}$, Fikri Hasan $^{2}$ \\ ${ }^{\text {I} P r o d i ~ I l m u ~ K o m u n i k a s i, ~ U n i v e r s i t a s ~ M e r d e k a ~ M a d i u n, ~ J l . ~ S e r a y u ~ N o .79, ~ M a d i u n, ~} 63133$ \\ E-mail: ryaristunugroho@yahoo.com \\ ${ }^{2}$ Prodi Ilmu Komunikasi, Universitas Merdeka Madiun, Jl. Serayu No.79, Madiun, 63133 \\ E-mail: fikri@unmer-madiun.ac.id
}

\begin{abstract}
Public communication skills are an unavoidable demand in an organization. Being an MC or being a speaker is a skill that must be possessed, and for that it needs to be learned. The MC and Dirigen Training for PKK's member of Kincang will be divided into several sections, namely general communication skills, public speaking, overcoming nervousness, and practice being MC and conductor. The purpose of this training is that PKK's members have good skills in public speaking so that they can carry out PKK's internal events well and smoothly. In addition to being useful in terms of hosting events as MCs, this public speaking skill is also useful so that PKK members are accustomed to speaking in public, including delivering socialization materials in other task. By having good communication skills, PKK's member can play a role in bringing official events in the village government so that they no longer need to hire or pay for a professional MC.
\end{abstract}

Keywords - : MC; public speaking; PKK; Kincang.

\section{PENDAhuluan}

Kegiatan MC dan protokoler serta keterampilan menjadi dirigen atau memimpin lagu menjadi bagian penting dalam acaraacara resmi. Keberadaan MC dan Protokol sangat dibutuhkan pada berbagai kegiatan seperti pertemuan resmi, kunjungan kerja, audiensi dan penerimaan tamu ataupun acara perjamuan. Di samping itu, juga dalam kegiatan kantor lainnya seperti lokakarya, workshop, konferensi, dan seminar. Kegiatan tersebut tidak lepas dari peran MC maupun petugas protokoler termasuk dirigen.

Kesuksesan suatu acara sangat tergantung pada kemampuan MC dalam mengendalikan acara serta perencanaan protokoler yang dipersiapkan. MC berfungsi memandu jalannya acara dari awal sampai akhir acara. Dalam kenyataannya, seringkali hal ini berjalan tidak baik yang disebabkan oleh kurangnya pemahaman dan keterampilan MC mengendalikan acara, termasuk dalam acara-acara resmi PKK desa Kincangwetan Kecamatan Jiwan Kabupaten Madiun.

Permasalahan yang sering ditemukan antara lain wawasan MC dan protokoler kurang memadai, penggunaan kalimat tidak baku atau pengucapan istilah-istilah yang salah, tata acara kurang sistematis, intonasi dan volume suara kurang tepat, dan sebagainya. Hal ini disebabkan karena : petugas MC kurang berlatih, anggapan bahwa MC \& protokoler tidak penting atau anggapan semua orang bisa menjalankan tugas sebagai MC dan dirigen, bahkan juga bisa disebabkan faktor pemimpin yang kurang peduli terhadap persoalan protokoler.

Sebagai salah satu unsur organisasi penting dalam lembaga pemerintahan di desa, PKK desa Kincang perlu memperhatikan tata tertib penyelenggaraan suatu acara termasuk memiliki keterampilan menjalankan tugas sebagai MC dan dirigen. Dengan demikian kegiatan pengabdian kepada masyarakat dengan memberikan pelatihan MC \& dirigen ini perlu dilaksanakan untuk meningkatkan wawasan dan kemampuan ibu-ibu anggota PKK Desa Kincang untuk menjadi petugas MC dan dirigen yang profesional.

Belum ada definisi yang merujuk pada Master of Ceremony (MC) dalam Kamus Besar Bahasa Indoensia (KBBI), namun terdapat istilah Pemandu Acara yang artinya adalah orang yang memandu atau memimpin acara. Selain itu ada juga istilah Pembawa Acara yang dalam KBBI berarti pengacara; pewara yang artinya adalah pembawa acara dalam suatu upacara, pertemuan, dan sebagainya. Sebagian ahli komunikasi publik membedakan pembawa acara dengan MC dilihat dari format acara, apakah resmi atau semi resmi. Istilah pembawa acara lebih lazim digunakan untuk acara-acara resmi, sedangkan MC lebih banyak digunakan untuk menyebut pembawa acara pada acara yang kurang resmi seperti pesta, hiburan, konser musik, dan sebagainya.(Sugono,2008)

Menyadari pentingya MC dalam suatu acara dimana MC adalah petugas utama penentu jalannya acara maka perlu diperhatikan hal-hal yang berkaitan dengan tugas seorang MC. Beberapa syarat yang perlu diperhatikan ketika menjadi MC antara lain :

1. Memiliki kesiapan mental yang kuat, hal ini terkait dengan penguasaan diri, penguasaan panggung, dan kepercayaan diri saat membawakan acara (tidak nervous atau canggung), termasuk ketika ada kejadian yang tidak diharapkan atau terjadi perubahan acara secara mendadak

2. Kemampuan menggunakan bahasa dengan baik dan benar, bisa membedakan penggunaan bahasa untuk acara formal (kedinasan), semi formal, atau acara santai. Demikian juga dalam hal pemilihan dan pengucapan kosa kata yang tepat. 
Website : http://dayamas.unmermadiun.ac.id/index.php/dayamas

3. Memahami rangkaian acara yang akan dibawakan sesuai tata urutan yang lazim berlaku baik dalam acara formal maupun semi formal dan acara hiburan.

4. Pandai menyesuaikan diri dengan suasana, berpenampilan menarik, dan bersikap santun.

Setelah mengikuti pelatihan, diharapkan ibu-ibu anggota PKK Desa Kincang memiliki kemampuan, sikap dan ketrampilan tentang bagaimana berperan dalam kegiatan MC dan protokoler sesuai rambu-rambu yang ada, mempraktikan pengetahuan, pemahaman dan ketrampilan teknis MC dan protokoler yang telah mereka miliki setelah mengikuti pelatihan.

\section{METODE PELAKSANAAN}

Kegiatan pengabdian kepada masyarakat ini berupa pelatihan keterampilan MC dan dirigen pada ibu-ibu anggota PKK Desa Kincang kecamatan Jiwan Kabupaten Madiun.

Pelatihan dan materi yang diberikan meliputi:

1. Definisi dan arti pentingnya MC dan protokoler

2. Ruang lingkup $\mathrm{MC}$ dan protokoler

3. Kualifikasi MC dan protokoler

4. Keterampilan dan tugas MC

5. Teknis Dirigen

Secara teknis, pelatihan dilakukan bertahap, dimulai dari pre-test berupa demonstrasi menjadi MC yang dilakukan oleh salah satu peserta untuk mengetahui kemampuan awal peserta sebelum mengikuti pelatihan. Dari tahap ini diketahui bahwa beberapa peserta sudah memiliki keterampilan yang cukup untuk menjadi MC dan dirigen.

Tahap berikutnya adalah pemberian materi mengenai definisi dan arti penting MC, ruang lingkup MC, kualifikasi MC, keterampilan dan tugas MC, serta bagaimana menjadi dirigen yang baik dan benar.

Penyampaian materi diberikan secara bertahap sambil dilakukan melalui demonstrasi/simulasi sehingga peserta diharapkan lebih mudah memahami materi yang disampaikan. Setelah penyampaian materi, dilanjutkan dengan praktik yang dilakukanlangsung oleh peserta. Masing-masing peserta diminta memilih acara apa yang akan dibawakan, apakah formal, semi formal, atau acara hiburan. Peserta juga diminta menyusun tata acara sesuai format acara yang akan dibawakan, kemudian satu per satu peserta mempraktikkan berbagai materi yang sudah disampaikan pemateri tentang berperan sebagai MC yang baik, meliputi penggunaan bahasa, pengaturan suara, sikap, dan aspek lain dari seorang MC. Penampilan peserta sebagai MC secara langsung akan dievaluasi bersama-sama oleh pemateri dengan menerima masukan dari peserta yang lain.

\section{III.HASIL DAN PEMBAHASAN}

Peserta pelatihan MC dan dirigen untuk ibu-ibu PKK dan kader Posyandu desa Kincang Kecamatan Jiwan Kabupaten Madiun ini adalah Ibu-Ibu PKK desa sejumlah 12 orang, perwakilan PKK dusun sejumlah 12 orang, dan Kader Posyandu sejumlah 6 orang. Sehingga jumlah peserta keseluruhan adalah 30 orang, 2 pelaksana kegiatan pengabdian, dan 2 tenaga bantu administrasi.

Pelatihan MC dan Dirigen telah dilakukan dengan baik, dimana peserta menunjukkan sikap antusias dalam mengikuti pemaparan materi dan menjalankan praktek pelatihan menjadi MC dan dirigen. Sedangkan materi yang diberikan meliputi:

1. Definisi dan arti pentingnya $\mathrm{MC}$ dan protokoler

2. Ruang lingkup $\mathrm{MC}$ dan protokoler

3. Kualifikasi MC dan protokoler

4. Keterampilan dan tugas MC

5. Teknis Dirigen

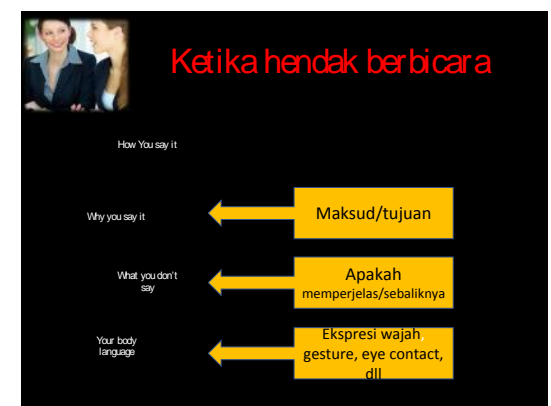

Gambar 1. Sebagian Materi Pelatihan 
Website : http://dayamas.unmermadiun.ac.id/index.php/dayamas

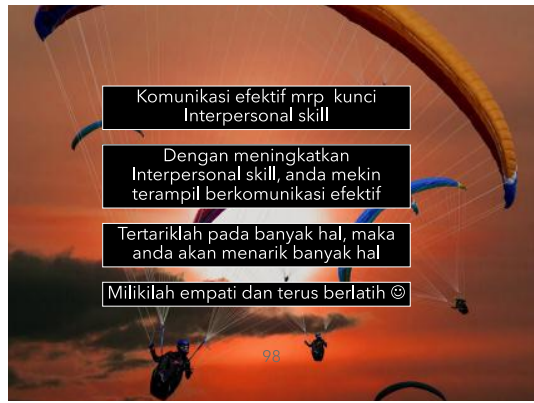

Gambar 2. Sebagian Materi Pelatihan

Hasil yang diperoleh dari kegiatan pelatihan keterampilan ini dicapai dalam pelaksanaan kegiatan ini antara lain :

1. Bertambahnya wawasan peserta mengenai keterampilan komunikasi di depan publik

2. Meningkatnya keterampilan peserta untuk mengendalikan acara sebagai MC

3. Meningkatnya keterampilan peserta dalam memimpin lagu sebagai dirigen

Sedangkan hambatan yang ditemui selama proses pelatihan diantaranya keterbatasan waktu pelatihan sehingga proses tidak berjalan maksimal, tidak semua peserta memiliki bakat berbicara di depan publik sehingga berpengaruh terhadap kepercayaan diri ketika tampil di depan peserta lain. Oleh karena itu disarankan untuk berlatih terus menerus, memberikan kesempatan untuk menjadi MC dan dirigen secara bergantian dalam acara-acara internal PKK, dan mengadakan lomba MC dan dirigen dalam even-even internal PKK.

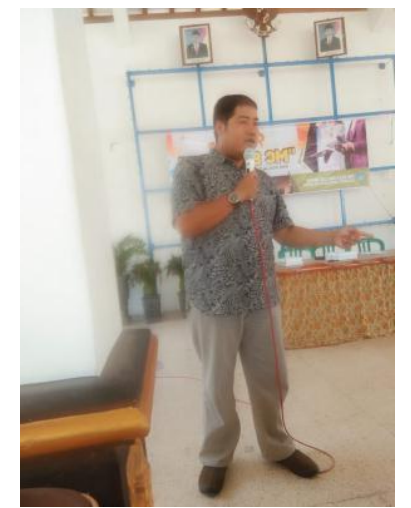

Gambar 3. Pemberian Materi Pelatihan

\section{IV.KESIMPULAN}

Secara keseluruhan kegiatan Pelatihan MC dan Dirigen sudah berjalan dengan lancar dan mendapatkan respon yang positif dari peserta. Seluruh peserta telah mengikuti program pelatihan dengan antusias. Meskipun tujuan akhir kegiatan ini adalah untuk meningkatkan keterampilan MC dan dirigen ibu-ibu anggota PKK desa Kincang kecamatan Jiwan Kabupaten Madiun, namun tidak serta merta menunjukkan hasil sesuai harapan. Namun diharapkan setelah pelatihan ini dilaksanakan, dapat menumbuhkan kesadaran, menambah pengetahuan dan pemahaman tentang kegiatan $\mathrm{MC}$ dan dirigen, serta memberikan bekal keterampilan praktis bagi peserta.

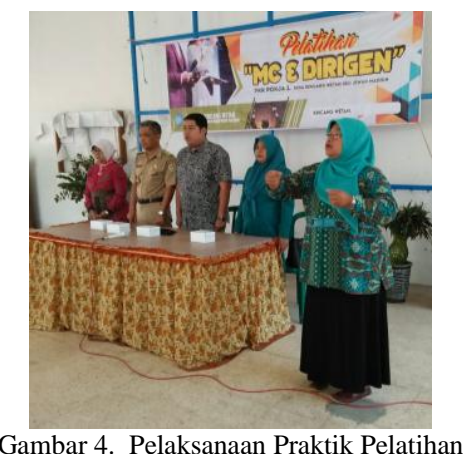

Sebagian besar peserta sudah dapat melakukan praktik secara langsung sebagai MC dengan menggunakan bahasa yang efektif, pengaturan intonasi suara yang baik, dan memiliki perilaku dan sikap sebagai seorang MC, serta aspek-aspek lain dari seorang MC. Oleh karena itu disarankan ibu-ibu anggota PKK desa Kincang ini tetap rajin berlatih hingga menguasai 
Website : http://dayamas.unmermadiun.ac.id/index.php/dayamas

keterampilan MC dan dirigen dengan sempurna sehingga bermanfaat bagi penyelenggaraan acara-acara di lingkup internal PKK Desa KIncang maupun pemerintahan desa Kincang bahkan bisa menjadi MC profesional.

\section{UCAPAN TERIMAKASIH}

Ucapan terima kasih disampaikan kepada LPPM Universitas Merdeka Madiun yang telah mendanai kegiatan pengabdian kepada masyarakat sebagai perwujudan Tri Darma Perguruan Tinggi, kepada Pemerintah Desa Kincang wetan, Tim Penggerak PKK Desa Kincang, dan pihak-pihak yang telah membantu terselenggaranya kegiatan ini.

\section{VI.DAFTAR PUSTAKA}

Sugono, Dendy. (2008). Kamus Bahasa Indonesia, Pusat Bahasa Departemen Pendidikan Nasional : Jakarta. 